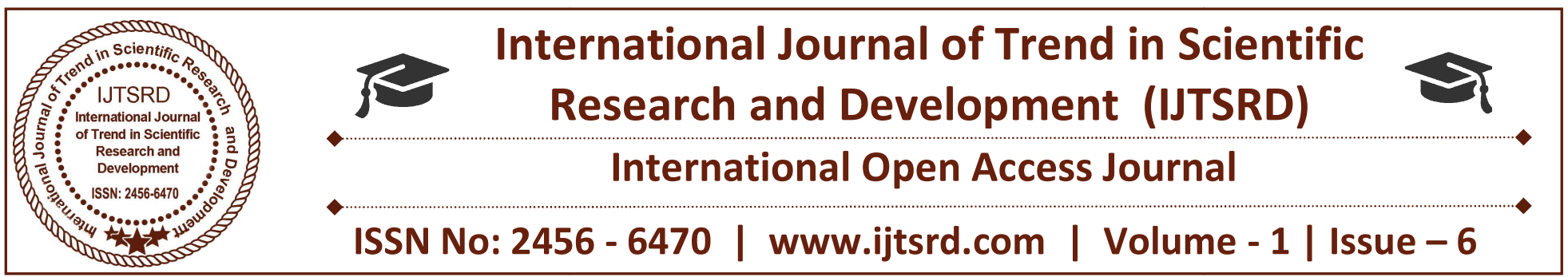

\title{
Innovative Pedagogies: Panacea for Students Academic Performance
}

\author{
Oso Senny Oluwatumbi \\ $\mathrm{Ph}$. D, Faculty of Education, \\ Department of Vocational and Technical Education \\ Ekiti State University, Ado-Ekiti, Nigeria
}

\begin{abstract}
Innovative pedagogies are paradigm shift in learning, redirecting teachers' role to facilitator of knowledge and rendering conventional method irrelevant and obsolete. The study examined Innovative pedagogies: Panacea for students' academic performance. A sample of 723 teachers from southern Nigeria was used for the study. Questionnaire titled 'Innovative pedagogies: Panacea for students' academic performance (TUIPPSAP)'
\end{abstract} was used to collect data.

The data collected were analysed using descriptive statistics of mean, simple percentages, t-test and Pearson Product Moment correlation at 0.05 level of significance. The results show that utilisation of innovative pedagogies had a positive significant relationship with students' academic performance. It was therefore recommended that teachers should constantly use innovative pedagogies to enhance students' academic performance.

Keywords: innovative pedagogies, panacea, students' academic performance

\section{Introduction}

Education is the total process of developing the mind to function properly in the society. As a part of human endeavour, it has witnessed tremendous innovation brought about by the employment of technology tools in teaching and learning processes. As the world is advancing rapidly, events are gradually moving to electronic age with computer at the centre which performs multi-functional roles in teaching and

learning processes. This new development has brought about revolution into teaching and learning process. Teaching that involves activities and problem solving, encourage students to learn real life problems based applied knowledge thereby sustaining the attention and understanding of the subject matter at its peak. Teaching according to Sunshine, Lawrence \& Juan (2015) is the most dynamic process in a teacher's life while learning also plays a dynamic role in a learner's life.

A lot of research has been carried out on how students learn. The constructivists believe students learn through self- exploration and active participation in learning process. A typical classroom environment dominated by the teacher does not encourage students participation hence hinders them from building the required involvement. The teacher transmits knowledge and the students receive. The teacher is the authority and central figure in delivering factual knowledge to the students who sit down to listen to the teacher talk, write notes, memorise and regurgitate. Researchers observe that the method is boring and ineffective because it is one way transmission of knowledge making students passive listeners with little or no feedback and understanding of the subject matter. Classroom teaching can be improved today through teachers' use of innovative teaching techniques by providing students' centred interactive learning environment. Application of innovative pedagogies can help erode the boredom and monotony in the class which sometimes results in unbelievable poor performance. 
The field of Education is witnessing revolution as a result of the use of technology application. Innovative pedagogies are paradigm shift in learning rendering conventional method of teaching irrelevant and obsolete in the contemporary education system. Such innovative pedagogies which include the use of technology instructional resources has redirected the role of the teachers from repository of knowledge to facilitator of learning and the learners on the other hand are no longer passive learners but active participants in the learning processes. In conventional method of teaching, the main teaching strategy is for the teacher to continue to talk to the students as passive learners. It has been discovered that this method does not suit the learning styles of all the students especially the slow learners. The students come from different background, with different learning styles and process information differently. If varied methods of teaching are not applied during learning process, they will not all be carried along. This could be attributed to why many students do not performance well academically. Students' academic performance is affected by many factors such as medium of instruction. Teachers' knowledge of the use of technology resources will enable them produce young Nigerians that can change the developmental pace of the Nation. Technology has made teaching and learning easy. Technology is a double edged sword that has revolutionised the world and educational system in particular. It is vital to confronting the problem of instructional delivery by improving teachers' teaching efficiency and to cut down students' failure. The use of technology resources provides myriads of opportunities for both teachers and students to harness and use to complement teaching and learning process.Observation has shown that an average student spends most hours on social media either chatting or browsing sites. Today learners are smarter than their teachers and prefer exciting and interacting learning environment. The opinion of the researcher is that teachers' employment of innovative technologies can redirect the student's curiosity to profitable learning outcome. It takes teachers who possess the technical know-how and the skills to satisfy the yearnings and desires of the students. Information and Communication Technology applications according toChen (2010) are emerging and designed that promote collaboration, connectivity and real world experience based learning as key pedagogical methods.
Research evidence abound from many fields of study that the falling standard of Education is a global phenomenon and many graduates from institutions of Higher Learning do not possess the skills to participate in today labour market. The academic performance of students plays important role in national manpower sustainable development as well as one of the factors considered by employer of labour in hiring workers. This depends to a great extent on teachers' qualification, experience, ability, training and adequate modern instructional facilities. Good teachers the importance of selection of appropriate methods, materials to enhance effective learning and students' performance. Teachers play a significant role in students' performance and can also contribute to their poor performance especially if the teachers lack experience, qualification, classroom management and teaching ability. This might hamper discussion and collaborative learning. Little wonder that the National Policy on Education states that no nation can rise above the quality of the teachers (NPE 2014). It also states that educational activities should be learner centred for maximum selfdevelopment and practice of self- learning.

In Angeli and Valannides (2009), research shows that in spite of the many efforts that researchers and educators put over the years in preparing teachers in the educational uses of technology, teachers still lack the skills and knowledge needed to be able to teach with technology successfully. This failure they attributed to inadequate preparation of teachers to teach with technology and the following reasons were advanced by them.

The teachers therefore have to develop the ability to utilize these innovative pedagogies to facilitate students' academic performance.

It has been observed that there is a marked deterioration in the academic performance of students in Nigeria and even globally. This situation is not cheering enough hence a clarion call to teachers and the advocacy to improve teaching methodology. National Information Technology Development Agency (NITDA) introduced mobile Internet Unit (MIU) to adequately equip schools with information and communication technology facilities to train teachers and students in the use of internet (Adomi and Kpangan 2010). 
Quality education cannot be achieved without a change of methodology. This led to the advocacy for the use of relevant and appropriate technology resources by teachers in teaching and learning process. Teaching and learning process should be exciting and motivating making students to always look forward to when next to be in the class. According to Adeosun (1998. 2002), learning should be fun and entertaining that will generate interest in the learners. Innovative pedagogies is gradually changing classroom experiences and making teachers more effective.

\section{The role of the teacher in application of innovative pedagogies teaching and learning}

The teacher plans, prepares and sets the tone of learning environment. He designs the broad range of learning strategies, materials, techniques, styles, techniques and implements appropriate instruction to meet the learners' learning needs. The teacher teaches with different relevant approaches to meet individual learners' learning styles and characteristics to ensure none is left out of the learning process. He uses varied method of teaching to transfer knowledge and skills to learners. He constantly evaluates, restrategise and make changes for improvement. The ability to restrategise and change methods depends on teachers' understanding of the various innovative pedagogies. Teachers' capabilities to enhance instruction will go a long way to improve students' performance but observation has shown that many teachers do not possess sufficient skills to integrate technology into teaching and learning process. Through the knowledge of innovative pedagogies, the teacher should be able to provide students with challenging and attainable learning tasks to help them improve their academic performance. The teacher can make or mar, build or pull down learners during learning process so he has to possess the skills to integrate modern pedagogy strategies into the teaching and learning process. Students should be allowed to think for themselves and the teachers on the other hand should depart from old pedagogies. Dewey (1938), states that the role of the teacher in teaching and learning process is to guide the students through rigorous academic routine that matches individual inclinations and ability of the students. He believes that the notion that learning involves students as cocreators and collaborative problem solvers is indeed an important one. Therefore teachers should involve pedagogy that will inspires learning practice hence there is the need to examine the professional practice and their impact on students' academic performance.

Chen (2010) posits that the profile of learners have changed due to the fact that they are 'digital natives' weaned on video games and web 2.0 who possess transformational change in their pockets in form of powerful multimedia handheld devices. These technologies have changed the traditional pedagogical paradigm thereby bypassing the educator to reach the students directly and revolutionizing their learning experiences. The onus is on the teacher to think on how to effectively restrategise and apply innovative pedagogies through the use of technology resources attract the attention of the learners who are already vast in the use of technology.Chen (2010) further stresses that many teachers today are lamenting that the learners are impossible to engage in learning process but games designers daily solving their problems with success. Little wonder Gee (2003) states that educators apply better learning principles because today learners have short attention span. Therefore teachers' pedagogical approaches should be congruent with their learning styles (Prensky 2010).

Collaborating learning is a teaching technique which can be called an innovative pedagogy involving the grouping of students together in order to impact knowledge. It is a paradigm shift in learning by deviating from the conventional method. Collaborating learning can take a variety of form. Researchers believe working together increases learning outcomes. Learning experiences that are active, engaging, learner-centred and encourage social interaction result in deeper learning. Students learn most by actively participating in learning process. In so doing they help the students to develop higherlevel thinking ability, increase students' retention, self-esteem, are able to have grip of the subject matter thereby enhancing their performance.

Teachers guide students to develop problem solving skills and have real life experience during teaching and learning process. For instance, students are be able to understand the relevance of concept in every subject taught in order to be able to apply it in the future. In the class where teacher uses collaborating learning students are observed to engage in discussion with peers, working cooperatively thereby developing teamwork and communication skills. These skills will definitely help the students in the future work force. 
Today there is innovation across the education system globally. The integration of technology resources into teaching and learning process is gradually being acknowledged. Osakwe(2012) assert that teachers need professional development not only in the use of technology resources but also in new pedagogical methods of incorporating technology into the classroom. Teachers can through innovative pedagogies help design hands-on projects and skills. To incorporate technology based activities into teaching and learning processes, the teacher has to have the technical know-how of the use of the tools. If the tools are used properly, they address individual learners' various learning styles and needs thereby enhancing their performance. The application of technology into pedagogical practice helps support more reflective and self-directed activities to enable learners to be competent adults in the future. The application of technology tools provides platform to create learning activities and set up inclusive learning environment that will allow for interactive project based activities to help students learn at their pace with fun.

The computer which is a combination of related devices capable of solving problems for instance is a technological innovation that can be used to perform some intellectual role in the classroom (Jonassen,D.H.,\& Reeves, T.C.1996). Computer as an innovative technology in teaching and learning process can provide dynamic interaction between students and instructional programme. As excellent and important technological tools are, they have not really gained root in teaching and learning process.

\subsection{Methodology}

The objective of the study is to examine the effectiveness of innovative pedagogies and

\subsection{Results and Discussion}

Question 1: What technology instructional resources are available for teachers to use innovative pedagogies? technology resources on students' academic performance. The instrument used was questionnaire which consisted of 20 items in two sections. Section A was on teachers' qualification and Section B was on utilisation of innovative pedagogies and technology resources. A sample of 723 teachers was selected through multi stage sampling technique. The first stage was the selection of the states through simple random sampling technique. The second stage was the random selection of the senatorial districts from each of the state. The third stage was also the random selection of the local government areas while the last stage was the selection of the secondary schools through stratified random sampling technique.

The data obtained were subjected to descriptive analysis and inferential statistics using Pearson Product Moment correlation and Analysis of Variance. The hypotheses were tested at 0.05 level of significance.

Two research questions were raised for the study

1. What technology instructional resources are available for teachers to employ innovative pedagogies?

2. What innovative pedagogies do you combine with technology to enhance students' academic performance?

Two hypotheses were generated from the research questions

1. Teachers' qualification does not significantly influence the use of innovative pedagogies.

2. There is no significant relationship between teachers' use of Innovative pedagogies and students' academic performance. 
Table 1

Summary analysis of technology instructional resources available to teachers to employ in innovative pedagogies

\begin{tabular}{|l|l|l|l|}
\hline & Technology aided Instructional Resources available for Teachers' Use & \multicolumn{2}{|l|}{ AVAILABLE } \\
\hline S/N & & Freq & $\%$ \\
\hline $\mathbf{1}$ & Filmstrips & 164 & 22.7 \\
\hline $\mathbf{2}$ & Slides & 202 & 27.9 \\
\hline $\mathbf{3}$ & Computer/ Printer & 125 & 17.3 \\
\hline $\mathbf{4}$ & Digital Still / Video camera & 125 & 17.3 \\
\hline $\mathbf{5}$ & Interactive Smart Board & 126 & 17.4 \\
\hline $\mathbf{6}$ & Educational Software Packages & 141 & 19.5 \\
\hline $\mathbf{7}$ & Animation & 124 & 17.1 \\
\hline $\mathbf{8}$ & Projector / Projector Screen & 149 & 20.6 \\
\hline $\mathbf{9}$ & Internet Connectivity/ E-Mail Facilities & 121 & 16.7 \\
\hline $\mathbf{1 0}$ & Power Supply & 129 & 17.8 \\
\hline Grand total & 1406 & 194.3 \\
\hline
\end{tabular}

Table 1shows that technology aided Instructional Resources were adequately available considering the low percentage scores of the resources. The implication is that these ICT resources were not sufficiently used by teachers in instructional delivery in public secondary schools in Southsouth States.

Question 2: What Innovative Instructional strategies do you combine with technology to enhance Students' Academic performance?

Table 2

Summary analysis of Innovative Instructional strategies combined with technology used to enhance Students' Academic performance

\begin{tabular}{|l|l|l|l|}
\hline S/N & $\begin{array}{l}\text { Innovative instructional strategies combined with technology } \\
\text { employed for teaching and learning process }\end{array}$ & Freq & $\%$ \\
\hline $\mathbf{1}$ & Collaborative learning/video clips & 55 & 7.6 \\
\hline $\mathbf{2}$ & Problem solving/video clips & 56 & 7.7 \\
\hline $\mathbf{3}$ & Drill and practice/ video clips & 28 & 3.9 \\
\hline $\mathbf{4}$ & Cooperative learning/CD & 94 & 13 \\
\hline $\mathbf{5}$ & Interactive instruction/social media & 103 & 14.2 \\
\hline $\mathbf{6}$ & Reflective discussion/internet & 10 & 1.4 \\
\hline $\mathbf{7}$ & Experiential learning/field trips & 25 & 3.5 \\
\hline $\mathbf{8}$ & Independent study/computer & 55 & 7.6 \\
\hline $\mathbf{9}$ & Presentation/power point & 121 & 16.7 \\
\hline $\mathbf{1 0}$ & Brainstorming & 103 & 14.2 \\
\hline
\end{tabular}

Table 2 reveals that teachers in the Southern Nigeria do not sufficiently use the innovative instructional strategies to enhance students' academic performance as indicated by the percentage scores on the table.

\section{Testing of Hypotheses}

Hypothesis1: Teachers' qualification does not significantly influence the use of innovative pedagogies. 
International Journal of Trend in Scientific Research and Development (IJTSRD) ISSN: 2456-6470

Table 3

ANOVA summary showing teachers' qualification innovative pedagogies.

\begin{tabular}{|c|c|c|c|c|c|c|}
\hline States & Source & SS & Df & Mean & F-cal & F-tab \\
\hline $\begin{array}{l}\text { AKWA } \\
\text { IBOM }\end{array}$ & $\begin{array}{l}\text { Between Groups } \\
\text { Within Groups } \\
\text { Total }\end{array}$ & $\begin{array}{l}1086.637 \\
53961.251 \\
55047.888\end{array}$ & $\begin{array}{l}4 \\
147 \\
151\end{array}$ & $\begin{array}{l}5.78 \\
19.09\end{array}$ & 0.740 & 2.10 \\
\hline DELTA & $\begin{array}{l}\text { Between Groups } \\
\text { Within Groups } \\
\text { Total }\end{array}$ & $\begin{array}{l}1567.646 \\
81139.550 \\
82707.196 \\
\end{array}$ & $\begin{array}{l}6 \\
366 \\
372 \\
\end{array}$ & $\begin{array}{l}261.274 \\
221.693\end{array}$ & 1.179 & 2.10 \\
\hline EDO & $\begin{array}{l}\text { Between Groups } \\
\text { Within Groups } \\
\text { Total }\end{array}$ & $\begin{array}{l}3523.940 \\
70565.196 \\
74089.136\end{array}$ & $\begin{array}{l}6 \\
192 \\
198\end{array}$ & $\begin{array}{l}587.323 \\
367.527\end{array}$ & 1.598 & 2.10 \\
\hline Total & $\begin{array}{l}\text { Between Groups } \\
\text { Within Groups } \\
\text { Total }\end{array}$ & $\begin{array}{l}3528.41421 \\
7312.75122 \\
0841.165\end{array}$ & $\begin{array}{l}6 \\
717 \\
723\end{array}$ & $\begin{array}{l}588.069 \\
303.086\end{array}$ & 1.940 & 2.10 \\
\hline
\end{tabular}

$\mathrm{P}>0.05$

Table 3shows that F-cal (1.940) is less than F-table (2.10) at 0.05 level of significance. The null hypothesis is accepted. Similarly, the effect of teachers' qualification on inAkwaIbom State $(F=0.740, p>0.05)$, Delta State $(\mathrm{f}=1.179, \mathrm{p}>0.05)$ and Edo $(\mathrm{F}=1.598, \mathrm{p}>0.05)$ is not significant at 0.05 level in each case. This implies that teachers' qualification has no significant influence on innovative pedagogies.

Hypothesis 2:There is no significant relationship between teachers' use of Innovative pedagogies and students' academic performance

Table 4

Pearson Product Moment Correlation summary showing teachers' use of innovative pedagogies and its utilisation to enhance students' academic performance.

south.

\begin{tabular}{|l|l|l|l|l|l|l|}
\hline States & Variables & Freq & Mean & SD & r-cal & r-table \\
\hline \multirow{2}{*}{ AkwaIbom } & Innovative pedagogies & 152 & 32.51 & 9.44 & $0.547^{*}$ & 0.195 \\
& Utilisation & 152 & 54.66 & 19.09 & & \\
\hline \multirow{2}{*}{ DELTA } & Innovative pedagogies & 373 & 34.54 & 7.76 & $0.558^{*}$ & 0.195 \\
& Utilisation & 373 & 58.49 & 14.91 & & \\
\hline \multirow{2}{*}{ EDO } & Innovative pedagogies & 199 & 32.22 & 11.39 & $0.737^{*}$ & 0.195 \\
& Utilisation & 199 & 50.21 & 19.34 & & \\
\hline \multirow{2}{*}{ Total } & Innovative pedagogies & 724 & 33.48 & 9.21 & $0.627^{*}$ & 0.195 \\
& Utilisation & 724 & 55.41 & 17.48 & & \\
\hline
\end{tabular}

$* \mathrm{P}<0.05$

The result on table 4 shows that there is significant, high, positive relationship between teachers' use of innovative pedagogies and technology resources in secondary schools in Southsouth States (r-cal 0.627, $\mathrm{p}<0.05)$ at 0.05 level of significance therefore the null hypothesis is rejected. Similarly, a significant correlation exists between teachers' innovative pedagogies and utilization technology resources in secondary schools in AkwaIbom (r-cal $=0.547$, $\mathrm{p}<0.05$ ), Delta (rcal $=0.558, \mathrm{p}<0.05)$, Edo (rcal $=0.737$,

\section{DISCUSSION}

The study revealed that there is a significant difference among public teachers' use of innovative pedagogies in secondary schools in Southsouth States. The reason adduced could be the level of availability and accessibility of the innovative instructional materials and technology resources and lack of skills in their utilization in various States. This study agreed with Osakwe (2012) and Amara S. (2006) who $\mathrm{p}<0.05$ ) at 0.05 level of significance. 
stressed that there is lack of qualified personnel to man the few available resources in secondary schools.

The findings of the study further revealed that teachers' qualification had no significant influence on innovative pedagogies utilization in public secondary schools in Southsouth States. There existed a significant positive relationship between teachers' use of innovative pedagogies and technology resources that means innovative pedagogies enhances students' academic performance in public secondary schools in Southsouth. The finding is supported by Heinich, Molenda, Russell and Smaldino(2002) that the inclusion of instructional mediain the teaching and learning encourages students' interactivity, sustain their attention and boost understanding. Technology resources help teachers acquire better skills to impart knowledge effectively where they are available.

As a result of the finding, it was therefore recommended among others that

Teachers should endeavour to constantly develop and update themselves by attending relevant workshops and seminars to keep abreast of the new innovation and trends in teaching and learning processes in order to enhance their effectiveness.

There is skill gaps in the labour force because graduates that are turned out each year lack practical skills therefore teachers should engage students in more practical skills more than theoretical work.

The government also should organize workshops and conferences for teachers to teach them the use innovative pedagogies and technology and more attention should also be paid to teachers' digital literacy in order to enable them to use it effectively to enhance students' academic performance.

The study is significant because it would add to existing literature on students' and teachers' development in innovative pedagogies utilisation and productivity in ICT pedagogy in secondary schools in Southsouth of Nigeria. The world is now a global village where every activity is being computerized, so the study will expose teachers at the grass root to innovative pedagogies and technology resources utilisation.

\section{REFERENCES}

1) Adeosun O.V. (1998), The technology of education, Greenline publishers, Ado-Ekiti.

2) Adeosun O.V. (2002), Relative effects of three multimedia packages on students and retention in social studies, Unpublished Thesis, University of Ado-Ekiti.

3) Adomi, E. E. \&Kpagban, E. (2010), Application of ICTs in Nigerian secondary schools. Library philosophy and practice. Retrieved from http://digitalcommons.unl.edu/cgi/ computing and ICT research.

4) Amara S. (2006), Computer literacy of teachers, department of census and statistics. Accessed from http.//www.statistics.gov.Ik/education /article.pdf

5) Angeli\&Valannides (2009)Pan African research agenda on the pedagogical integration of ICTs, UNESCO-IICBA, Addis Ababa.

6) Chen, M. (2010) Education Nation: Six learning edges of innovation in our schools. Francisco, CA: Jossey-Bass

7) Dewey, J. (1938) Experience and Education. New York: Collier Books,pp25-50

8) Federal Republic of Nigeria (FRN) (2004) National Policy on Education, Lagos: NERDC Press.

9) Federal Republic of Nigeria (FRN) (2014) National Policy on Education, Lagos: NERDC Press.

10) Gee, J.P. (2008)what video games have to teach us about learning and literacy, revised and updated, Basingstroke: Palgrave Macmillan

11) Heinich, R. Molenda M. Russell, J.D.\&Smaldino, S.E. (2002).Instructional media and technology. New Jersey: Prentice hall 07632

12) Jonassen,D.H.,\& Reeves, T.C. (1996).Learning with technology: Using Computer as Cognitive Tools. In Jonassen,D.H. (Ed.), Handbookofresearch for educational communications and technology $\left(1^{\text {st }}\right.$ ed.), Retrieved from http: //www.aect.org/edtech/ed1/.

13) NITDA (2003).Use IT: National information technology development Agency Abuja, Nigeria. Available:http://www.nitda.gov.ng/use it.htm

14) Osakwe R.N.(2012) Challenges of ICT education in Nigerian public secondary schools, education research journal 2(12)388-391.

15) Prensky, M. 2010) Teaching Digital Natives: Partnering for Real Learning. Thousand Oaks: CA: Corwin Press.

16) Sunshine, B.A, Lawrence, C.C\& Juan J.T.D (2015)Factors Affecting the Academic Performance of the Student Nurses of BSU. International Journal of Nursing, Science 2015 (5)2: 60-65 DOI: 10.5923/j.Nursing.20150502.04 